\title{
2.6 Фактори, що впливають на організацію багатоповерхових житлових будинків
}

Українські вчені проаналізували найважливіші показники рівня розвитку і поширену поверховість житлових будинків в різних країнах світу. Виявлено пропорційну залежність поверховості багатоквартирного житла для постійного проживання від загального рівня розвитку країни: чим вище рівень життя в країні, тим менше поверховість будинків.

Ця залежність дійсна лише щодо житла, призначеного для постійного проживання. Також проведено аналіз, на основі отриманих результатів якого виявлено три основні варіанти розміщення багатоповерхової забудови на території міст різних країн світу: багатоповерхова забудова в історичному центрі

міста (США, Канада, Австралія), багатоповерхова забудова, віддалена від історичного центру міста (країни Західної і Центральної Європи), змішана забудова (країни, що розвиваються).

Проблеми багатоповерхового житла пов'язані з цілою низкою соціальноекономічних обставин, що мають об'єктивний і суб'єктивний контекст. Основними проблемами багатоповерхового житла є: порушення взаємозв'язку людини і природи; погіршення санітарно-гігієнічних умов; ускладнення заходів безпеки проживання і подорожчання експлуатації будівлі; психічні розлади у мешканців.

Світова практика містобудування свідчить про усвідомлення в суспільстві того, що багатоповерхові будинки не повинні бути житловими. В умовах активного економічного і соціального розвитку міст архітектура перетворюється на дієвий фактор ефективного вирішення проблем сучасного урбанізованого світу. В результаті аналітичного огляду було виділено фактори, що впливають на поверховість та комфортність багатоквартирного житлового будинку.

Природно-кліматичні чинники враховують особливості клімату місцевості, впливають на архітектуру житла, його функціональну і просторову організацію, 
вибір конструкцій, матеріалів. До них відносять: інсоляцію, температуру та вологість повітря, шумовий, вітровий, аераційний режими, вентиляцію.

Для формування комфортного житлового середовища необхідно враховувати характеристики регіонального і локального мікроклімату. Регіональний напрямок пов’язаний з урахуванням загальних умов клімату, характерних для великих територій, районів, міст. На регіональному рівні до житла пред’являють загальні типологічні вимоги, регламентовані нормами. Локальний мікроклімат обумовлений особливостями конкретної місцевості. На цьому рівні уточнюють типологічні вимоги до житла. Житлові будинки набувають певну спрямованість у зв'язку з місцевим напрямком вітрів, 3 конкретними умовами інсоляції, орієнтації схилів, видових перспектив і т. п.

Індивідуальний мікроклімат в багатоповерховому житловому будинку створюють з урахуванням регіонального та локального клімату. Він повинен створюватися в системі інтер'єрних і екстер'єрних просторів. Інсоляція повинна забезпечувати достатнє потрапляння прямого сонячного світла всередину приміщень будинку. Обмежена прозорість скління світлопрорізів, їх затемненість, а часто невідповідність розмірів площі вікон глибині приміщень викликають дефіцит природного світла, що погіршує умови життя людини. Можливий перегрів приміщення в спекотні літні дні усувають за допомогою козирків, жалюзі, штор, озеленення. Акустичний режим залежить від зовнішніх i внутрішніх джерел шуму. Згідно 3 нормами, рівень шуму не повинен перевищувати 25 дБ і 20 дБ (в нічний час). Додатковими джерелами шуму є: ліфтове обладнання, обладнання відведення води, система центрального кондиціювання, вентиляції і т. п. Рівень шуму може бути зменшений засобами раціонального планування будинку, його озеленення, застосування шумозахисних матеріалів. Згідно з результатами досліджень в сфері звукових коливань житловий будинок може відповідати вимогам акустичного комфорту завдяки його обмеженню 5-ю поверхами. Вологість повітря прямим чином впливає на здоров’я і самопочуття людини: високий рівень призводить до ослаблення імунної системи, виникненню різних захворювань і алергічних 
реакцій, занадто низький негативно впливає на людський організм в цілому. Тому рівень відносної вологості повітря в житловому будинку з комфортним мікрокліматом - 40-60\%.

Істотно впливає на планування житлового утворення вітровий режим місцевості. Раціональне проектування житлового будинку з урахуванням вітрів передбачає ефективне використання природного провітрювання приміщень та зниження негативного впливу вітрового напору. В цілому індивідуальний мікроклімат формують з урахуванням умов підвищених і знижених температур. Ландшафтні фактори враховують характер природного середовища.

Рельєф місцевості значно впливає на вибір прийомів житлової забудови і формоутворення будинків. Як правило, на крутих схилах розташування житлових будинків безпосередньо залежить від пластики рельєфу. Забудова цих територій вимагає додаткових інженерних заходів для їх підготовки та обладнання. Несприятливими для житлової забудови є північні схили, так як на них не відбувається інсоляція приміщень і території. Слід підкреслити, що освоєння крутих схилів для забудови є дуже актуальним завданням, оскільки більшість великих міських поселень вже вичерпали свої територіальні резерви. Містобудівні фактори (місце розташування та розміри ділянки будівництва, морфологічні особливості навколишньої забудови, іiі функціональна структура) активно впливають на формування житлових будинків. У місті, яке має тривалу історію розвитку, будівництво житлових будинків може бути здійснене в умовах реконструкції центральних районів і на нових освоюваних територіях. Ділянка може бути відведена на магістральній вулиці і всередині кварталу, на міській площі і в пішохідній зоні, в складі житлового комплексу і в суспільноадміністративному центрі. Аналогічні ситуації можна зустріти в новому місті. Тому при проектуванні житлового будинку і забудови в цілому необхідно комплексно враховувати специфіку ситуації. Так істотне значення для проектування житлових будинків має морфологія навколишньої забудови (геометрія її планів, розмірність будівель і утворених ними просторів). 
Компонування будівель і комплексів, що розміщують в історичних центрах, як правило, орієнтовано на підтримання і в ряді випадків повторення геометричних конфігурацій і розмірностей, властивих оточенню. У районах, що виникли в 60-70-і роки, навпаки, більш привабливим може виявитися не уподібнення, а контраст, якого досягають засобами зменшення дворових просторів i ускладнення геометричних характеристик планів. Важлива властивість міського середовища - поверховість формуючих ії будівель.

У зонах суворо регульованої забудови, заснованої для збереження архітектурної та містобудівної спадщини, визначають гранично допустиму висоту новозведених споруд. Для кожного місця обмеження встановлюють індивідуально на основі вивчення ситуації. Поверховість проектованих багатоповерхових житлових будинків може бути лімітована також і з метою збереження видів на ландшафтні і архітектурні пам’ятки. В інших випадках поверховість регулюють, виходячи 3 інших міркувань, в тому числі композиційних.

Великий вплив на проектування багатоповерхового житла надає функціональна структура міського середовища. У практиці останніх років помітне місце займає будівництво житла в складі багатофункціональних комплексів і у вигляді будинків з вбудованими або прибудованими закладами громадського призначення.

Еколого-гігієнічні фактори комфортності: коливання будинку, атмосферний тиск, хімічний склад повітря, озеленення прибудинкових територій. Коливання багатоповерхових будинків чинять негативний вплив на вестибулярний апарат людини і можливість входження їх в резонанс з низькочастотними коливаннями внутрішніх органів людини. Обидві причини можуть викликати небезпечні психофізичні розлади організму i хронічні захворювання. 3 точки зору уникнення негативного впливу можливих коливань будинку поверховість житла для постійного проживання запропоновано обмежити 12-ма поверхами.

Атмосферний тиск визначено одним 3 показників комфортності житла. Вважається, що до висоти 100 м рівень тиску порівняно стабільний, але навіть на 
висоті 20-поверхового будинку (60 м) тиск менше на 8-10 мм від тиску на рівні 5 м над землею. Зниження атмосферного тиску спостерігається в міру віддалення від земної поверхні і погіршує самопочуття людини.

Отже, поверховість житлових будинків в цьому відношенні запропоновано обмежити 9-ю поверхами. Зміни в хімічному складі повітря 3 підвищенням висоти можуть бути небезпечними для здоров’я людей похилого віку і дітей. Зі збільшенням висоти розрідженість повітря безперервно збільшується, а тиск зменшується. Зростає температура, вологість, концентрація оксиду вуглецю i пилу. 3 цієї причини в багатоповерховому житлі повинна бути передбачена централізована система вентиляції та кондиціювання повітря. Однак кондиційоване повітря може негативно впливати на стан здоров’я мешканців, тому необхідним є природне провітрювання. Озеленення територій визначено як один $з$ факторів комфортності в аспекті створення безпечного для здоров’я людини мікроклімату багатоквартирного житла.

Демографічні та національно-побутові чинники враховують цілу низку ознак: чисельність і темпи зростання населення, його статевовіковий склад, число, розмір і структура сімей. Показники, що характеризують загальну чисельність населення важливі при визначенні об'ємів і темпів будівництва житла. 3 показниками статевовікової структури населення безпосередньо пов’язана типологія житлових будинків і квартир. Суттєве значення має факт старіння населення, що призводить до збільшення чисельності груп пенсійного віку.

Певний вплив на проектування квартир в багатоповерховому будинку має рівень освіти населення. 3 підвищенням рівня освіти зростають потреби в квартирах 3 можливістю створення робочого місця. Проектування житла неможливо без урахування сімейного складу населення, що впливає на формування типології квартир. Демографічні дані дозволяють зблизити структуру нового житлового фонду і попит населення. Важливою ознакою є структура родини. 
Соціально-психологічні чинники. Форми житла виникають і розвиваються в прямому зв’ язку зі способом життя окремих людей і соціальних груп. Усім видам житла притаманні деякі загальні соціальні функції: збереження здоров’я людей, що в ньому проживають; зміцнення сім’ї та створення в ній здорового психологічного клімату; сприяння розвитку сім’i; організація позаробочого часу; підвищення професійної кваліфікації; виховання дітей; створення умов для відпочинку; виконання ролі психологічного «притулку». Кожна з цих функцій повинна отримати певне матеріальнопросторове втілення, як в структурі всього будинку, так і в окремій квартирі.

Соціальна модель житла - це система вимог сім’ї до його функціональної програми і просторової структури. Вимоги визначають способом життя людей: сукупністю форм і умов життєдіяльності індивідуума, соціальної групи, суспільства. Так виникає необхідність цілісного підходу в архітектурній інтерпретації системи «спосіб життя - житлове середовище». Відступ від системного формування житлового середовища завжди обертається значним збитком для населення. На сучасному етапі набуває великого значення облік різноманіття індивідуальних і колективних потреб, висунених до житла. Кожна сім’я прагне організувати процеси життєдіяльності в квартирі з можливістю максимальної реалізації своїх професійних інтересів, ціннісних орієнтацій і звичок. Тому актуально питання про розширення номенклатури квартир i гнучкість їх архітектурно-планувальних параметрів. По-справжньому гуманне тільки те житло, яке в повній мірі відповідає своєму соціальному призначенню.

Eстетичні фактори. Предметне втілення естетичних ідеалів і традицій в архітектурі житла здійснюється в ході його формоутворення на всіх рівнях: забудова - будинок - велика пластика будинку - деталь - квартира. При вирішенні певних композиційних завдань визначають конкретні характеристики забудови: стилістичні ознаки, системи пропорцій і масштабність, метро-ритмічні закономірності, малюнок деталей, матеріал і фактура огороджувальних конструкцій, колір і т.п. У зарубіжній практиці крім цього велике значення надається суспільній оцінці вигляду міста, перевагам жителів, визначенню 
особливо значущих для населення якостей міського середовища, розкриття образних уявлень про місто, що склалися в свідомості людей. Подібна інформація допомагає точніше сформулювати проектну задачу і обгрунтовано вибрати засоби ії вирішення, вписати багатоповерховий будинок в середовище. Залежно від умов сприйняття і ролі будинку в заданій ситуації необхідно відображати його активність або пріоритетність. Чим далі об’єкт сприйняття, тим більша його частина потрапляє в поле зору. Окремий будинок починає сприйматися разом з оточенням і оцінюється в порівнянні з сусідніми будівлями. У міру віддалення від об’єкта сприйняття змінюється зміст цілого і частини. Так само змінюються просторові відчуття. Істотною умовою виявляється швидкість пересування глядача. Отже, забудова повинна бути досить інформативною для сприйняття при різній швидкості руху. Різноманітність зорового сприйняття житлових будинків актуалізує всі їх характеристики: від загальної форми до малюнка балконних огороджень i віконних рам. Нехтування будь-яким інформаційним елементом призводить до збіднення архітектурних якостей забудови.

Інженерно-технічні фактори: площа інженерних, комунікаційних і конструктивних елементів, системи і методи зведення будівель; інженерне обладнання; будівельні матеріали. Інженерне обладнання сучасного будинку дуже різноманітно, призначене для створення комфортних умов проживання та передбачає системи: опалення, вентиляції, водопостачання, каналізації, ліфтового господарства, сміттєвидалення, а також електромережу, газопровід, слабкострумові мережі, телевізійні кабелі тощо. У багатоповерхових житлових будинках потрібно обладнання технічного поверху для горизонтальної розводки мереж, ліфтова шахта і сміттєпровід. У деяких країнах система сміттєвидалення включає також і первинну обробку сміття. Широке застосування отримали санітарно-технічні кабіни. Для опалення будинків найчастіше застосовують радіатори 3 нагрітою водою. Також є системи променевого опалення, коли обігрівальні елементи розміщують за підвісною стелею або всередині стінових панелей. В даний час поширений прийом - система теплої підлоги. 
Техніко-економічні чинники формують огороджувальний простір будинку матеріально-конструктивну оболонку будівлі; відображають технічні та економічні можливості забудовника. При проектуванні багатоповерхових житлових будинків зростає значення раціонального використання матеріальних, фінансових і трудових ресурсів, спрямованих на вирішення житлової проблеми.

У США, Австралії, Канаді та країнах ЄС відповідність експлуатаційних витрат рівню комфортності житлового будинку є важливим критерієм при виборі житла. У міру збільшення економічного потенціалу суспільства і вдосконалення організації проектнобудівельної справи будуть зростати можливості для підвищення комфорту житла і поліпшення його архітектурних якостей. Bсі вищевикладені фактори впливають на архітектурні особливості житлового будинку і $є$ формотворчими. Своєрідності архітектури житлових будинків досягають в результаті всебічного i індивідуального врахування всіх вищезазначених чинників. Багаторічний світовий досвід висотного будівництва та відповідні наукові дослідження свідчать про різні прийоми розміщення хмарочосів у міському середовищі. Для забудови відносно молодих міст (НьюЙорк, Глазго та інші), в яких немає значних історичних архітектурних споруд, характерним є формування центральної частини міста за рахунок нових, в тому числі і багатоповерхових будівель. Це має певні позитивні містобудівні аспекти, особливо в архітектурно-композиційному відношенні та економному використанні територіальних ресурсів, адже вартість землі в сучасних мегаполісах надто висока. Однак під час будівництва хмарочосів в центральній частині міста ускладнюються проблеми транспортно-містобудівного характеру та створення необхідної інженерної інфраструктури.

Інша концепція розвитку, яка застосовується переважно в містах зі своєрідною історичною забудовою, не передбачає спорудження хмарочосів в центральній частині міста. В більшості історичних міст Західної Європи нові багатоповерхові громадські комплекси формуються переважно в периферійних зонах. Прикладом може бути Париж, де висотна офісна споруда «Тур де Монпарнас» (57 поверхів) в центральній частині міста не викликала особливого 
захоплення фахівців та мешканців міста. Тому в 1960-70-х роках створено сучасний діловий та громадський центр в восьми кілометрах від історичного центру в районі Дефанс з метою активізації економіки та придання нового стильового звучання архітектурі міста. За сучасними вимірами висоту будинків в новому районі Парижу неможна віднести до хмарочосів. Взагалі генеральним планом даної місцевості багатоповерховим (переважно офісним) будинкам віддавалось лише 5 відсотків території, житло передбачалося середньої поверховості, а громадські установи культурно-дозвільного, торговельного та виставкового призначення розмістились в малоповерхових спорудах зальної структури.

Дещо подібними є підходи до висотної забудови в Берліні. Нова забудова в центральному районі Фрідріхштадт регламентована максимальною висотою в 30 м. Висотні будинки в новому діловому та громадському центрі Потсдамер Плац обмежені 25 поверхами. Відносно менше обмежень стосовно висотності забудови в інших містах Німеччини, особливо у Франкфурті-на-Майні, де поряд 3 колоритним історичним ядром сформовано діловий центр зі своєрідними висотними архітектурними акцентами (рис. 1).

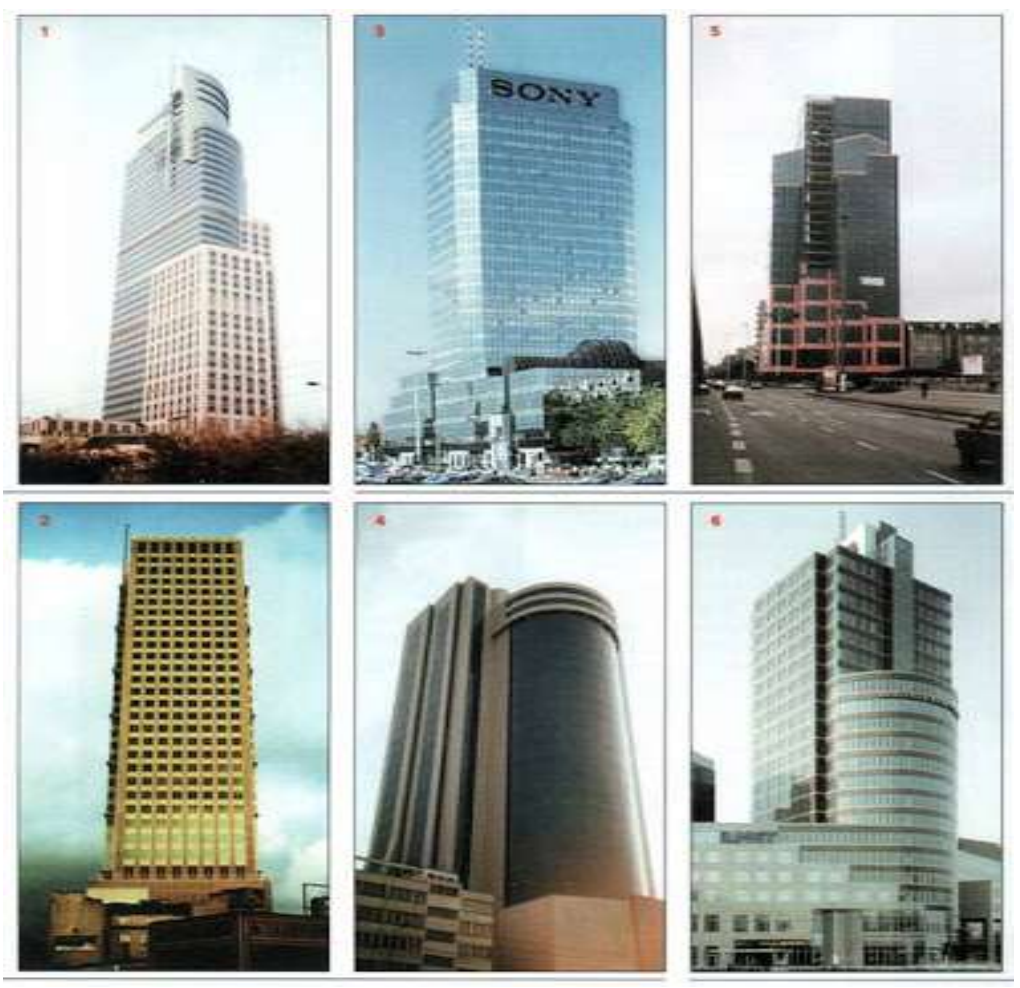

Рисунок 1 - Висотні забудови 
Дослідники проблем висотного будівництва відмічають, що у Лондоні також більш ліберальні підходи до нових висотних містобудівних акцентів, ніж у інших столичних містах Західної Свропи [148]. Незважаючи на те, що на протязі більше двох віків знаковою домінантою міста був і залишається Собор Святого Павла (120 м) та башти парламенту, в даний час в столиці Англії реалізується декілька висотних ділових комплексів: район Лондон Сіті, центр Канарі Уорф, група висотних споруд в районі Саутворк та інші. Керівництво міста сприяє подальшій урбанізації історичного середовища, висота споруд державними указами не регламентується.

Творення міського простору - одне з найважливіших людських зусиль, адже йдеться про те, щоб різні групи людей жили разом у відносній гармонії одне 3 одним та природою. Останнє є критично важливим, беручи до уваги драматичні наслідки змін клімату. Це має бути основним правилом будь-яких майбутніх креативних ініціатив в архітектурі міста. Планування, яким ми його знаємо, все ще сильно концентрується на фізичних аспектах, - урбаністичному дизайні та архітектурі. Воно добре виглядає з висоти пташиного польоту, тому зазвичай демонструється згори, але це не все, що має значення в містобудуванні. 